\title{
Chemical features, cholesterol and energy content of table hen eggs from conventional and alternative farming systems
}

\author{
R.M. Radu-Rusu1, M.G. Usturoi ${ }^{1 \#}$, A. Leahu ${ }^{2}$, S. Amariei ${ }^{2}$, C.G. Radu-Rusu ${ }^{1}$ \\ \& I. Vacaru-Opriş ${ }^{1,3}$ \\ ${ }^{1}$ University of Agricultural Sciences and Veterinary Medicine, Animal Science Faculty, 700489, 8 Mihail Sadoveanu \\ Alley, laşi, Romania \\ 2 "Ştefan cel Mare" University, Food Engineering Faculty, 13 Universităţii Str., 720229, Suceava, Romania \\ ${ }^{3}$ Academy of Agricultural Sciences and Forestry, B-dul. Marasti Nr. 61, Sector 1, Bucharest, Romania
}

(Received 8 January 2012; Accepted 22 October 2013; First published online 8 February 2014)

\begin{abstract}
Copyright resides with the authors in terms of the Creative Commons Attribution 2.5 South African Licence.
See: http://creativecommons.org/licenses/by/2.5/za

Condition of use: The user may copy, distribute, transmit and adapt the work, but must recognise the authors and the South African Journal of Animal Science.
\end{abstract}

\begin{abstract}
This study was carried out to investigate the effect of conventional farming systems for laying hens (standard cage batteries) and new alternative systems (improved cages and free range), approved by European Union (EU) poultry welfare legislation, on the chemical and nutritional quality of table eggs. The biological material consisted of eggs laid by 1200 Lohmann Brown hens, aged 27 weeks, fed similarly (a corn-wheat-soymeal diet). Conventional AOAC methods were used to analyse the eggs, and gross energy was calculated based on organic matter energy. All data were subjected to ANOVA statistical computation. The eggs produced in conventional cages compared with those laid in free-range farming conditions, presented significantly higher concentrations of total lipids $(11.40 \pm 0.65 \mathrm{~g} / 100 \mathrm{~g}$ vs. $10.78 \pm 0.87 \mathrm{~g} / 100 \mathrm{~g})$, cholesterol $(211 \pm 6.31 \mu \mathrm{g} / \mathrm{egg}$ vs. $202 \pm 7.79 \mu \mathrm{g} / 60 \mathrm{~g}$ egg) and gross energy $(0.36 \pm 0.007 \mathrm{MJ} / \mathrm{egg}$ vs. 0.35 $\pm 0.012 \mathrm{MJ} / \mathrm{egg}$ ). Consequently, it could be stated that under similar dietary conditions, the cage-free system influenced hens to produce eggs with a higher nutritive value than in the other systems.
\end{abstract}

Keywords: Battery cages, chemical composition, dietetic value, improved cages, free-range, laying hens \# Corresponding author: umariusg@gmail.com

\section{Introduction}

Changes in poultry husbandry technology and housing systems, because of the need to comply with fowl welfare requirements, have triggered several studies into the ways in which the use of a new rearing and management system could affect the behaviour of hens, the safety and quality of edible poultry products (meat and eggs), the economic efficiency of production (Miao et al., 2005; Usturoi \& Radu-Rusu, 2006) and consumers' marketing preferences.

In terms of behaviour and welfare status, it was shown that laying hens generally preferred nesting in furnished cages. Freedom of movement, dust bathing, scratching and roosting behaviours are signs that the fowl adapt well to improved cages, because these conditions try to imitate those from the natural environment or from the deep litter system (Bessei, 2010). All cage systems tend to provide a more hygienic environment with low risk of parasitic and bacterial disease and, consequently, lower the probability of contamination of edible products, including eggs (Blokhuis et al., 2007). The safety of the internal compartments of eggs in the new alternative poultry production systems could be altered microbiologically (Salmonella enteritidis and other pathogens) and chemically (dioxins, pesticides, and heavy metals). Season, hen breed, flock age and flock disease-vaccination status also interact to affect egg safety and quality, and must be taken into account (Holt et al., 2011). Therefore, the reason must be clear when choosing the husbandry system of laying hens, in order to provide a safe but economically reliable product for the market.

In general, in human nutrition, the total lipid proportions in foods and their components (e.g. cholesterol, fatty acids) are of concern. However, Nau et al. (2010) stated that the supposition that high cholesterol content has a negative influence on cardiovascular disease dynamics is a misjudgement since it is not supported by most human nutrition and cardiology epidemiological studies. In poultry products, for 
instance chicken meat, certain investigations (Aguiar et al., 2008) have revealed a higher lipid content and a lower proportion of polyunsaturated fatty acids (especially omega-3) in conventionally produced broilers, compared with broilers from other husbandry systems, such as organic or free-range farming. Moreover, the alternative systems provided meat with a lower cholesterol concentration. The effect of alternative production systems on egg quality is unresolved. Cherian et al. (2002) focused on the proximate composition and nutrients of the eggs from different husbandry systems applied in farming with laying hens, but found they were influenced mainly by feed quality. Thus, in free-range or cage-free systems, the proportion of the yolk was lower than in other systems, which differed mainly in diet, while no difference was reported on the total polyunsaturated fatty acid concentrations of eggs. However, in a study conducted with commercial eggs, Hidalgo et al. (2008) showed that, from a nutritional point of view, there were slight differences in proteins and saturated fatty acid concentrations, but the real variations were minimal when eggs from conventional cages were compared with those from alternative production systems. No significant differences were found in unsaturated fatty acids composition, although the eggs used in the study were bought from the market, and would probably have been subjected to errors in interpretation, assuming that the hens from different farms were fed mixed feed of varying quality and composition. Shapira (2010) stated that through egg composition elasticity because of hen diet compounds, table eggs could provide consumers with nutritional and functional benefits. Even if consumers perceive that the dietetic and nutritional values of free-range eggs are better than those of cage-produced eggs, a study revealed that free-range eggs had more total fat, although the cholesterol level in eggs was not influenced by the housing environment (Anderson, 2011). Small differences were found in saturated fatty acid content of organic and conventional eggs, and could have significant metabolic effects on consumers (Samman et al., 2009).

In aviculture practice and research, many methods were tried (and sometimes succeeded) to reduce the concentration of so-called undesirable nutrients in eggs, such as cholesterol and saturated fatty acids, and to improve the balance between polyunsaturated fatty acids. One of the ways of achieving these goals is by manipulating the diet. The omega- 3 fatty acid proportion relative to the omega- 6 fatty acids could be improved with fish oil or the addition of alpha-linoleic-acid (as omega-3 precursor) in feed. This could be complemented with vitamin $\mathrm{E}$ as an antioxidant (Sparks, 2006), through a dietary combination of fish and linseed oils (King et al., 2012), or through diet supplementation with dried purslane (Portulaca oleracea) (Aydin \& Dogan, 2010) or pumpkin seeds (Celik et al., 2011). Eggs enriched in unsaturated fatty acids and vitamins, through additions to layer diet of linseed, minerals, vitamins and lutein, proved to improve blood levels of omega-3 fatty acids, HDL-, LDL-cholesterol and triglycerides, in both experimental animals and human volunteers (Bourre \& Galea, 2006). Cholesterol concentration in eggs could be significantly reduced through diet supplementation with fish oil and flaxseed (Basmacioğlu et al., 2003). Certain feed additives showed promise, such as beta-cyclodextrin (Sparks, 2006), inulin (Shang et al., 2010), 0.5\% multispecies probiotics (Khan et al., 2011), antioxidant, vitamins E or C (Mohiti-Asli \& Zaghari, 2010), combinations of garlic and black tea (2\%) (Azeke \& Ekpo, 2009), 0.5\% ginger root powder (Akbarian et al., 2011), up to 3.0\% Nigella sativa (Islam et al., 2011) and pumpkin seeds (Celik et al., 2011). No effects on the total cholesterol content of eggs occurred when layer diets were supplemented with aromatic herb oils (thyme, sage or rosemary) (Bolukbasi et al., 2008), dried purslane (Aydin \& Dogan, 2010), garlic juice (Mahmoud et al., 2010) and plant sterols (Liu et al., 2010). Other reports showed that certain feed ingredients, such as lysolecithin could increase the cholesterol content of yolk (Han et al., 2010). Alternative ways of obtaining low cholesterol eggs could be avian genomics and transgenesis through the manipulation of key genes that control the production of those peptides that influence sterol absorption in the intestine, lipoprotein and cholesterol synthesis in liver and their transfer to the growing follicles containing future yolks. Even if these ideas are promising, they are highly influenced by bioethics, consumer acceptance and technological costs (Elkin, 2007). Artificial selection techniques have also been used successfully to decrease the cholesterol content in hen eggs, with significant results being achieved after 19 to 31 fowl generations (Baumgartner et al., 2008; Tercic et al., 2010). Certain interactions are suspected between fowl strains and their capability to take up dietary nutrients and transfer them to their products (eggs, meat). Thus, cholesterol seems to be higher in the eggs of commercial layers and lower in local pure breeds, while the hybrids lay eggs with better proportions of unsaturated fatty acids (Sarica et al., 2009). Despite these results, other studies revealed that yolk cholesterol was found at higher concentrations in local Mediterranean laying hen breeds compared with commercial laying hybrids, while fatty acid profiles of meat and yolk were influenced significantly by genotype (Rizzi \& Chiericato, 2010). Other methods could be used to reduce cholesterol concentrations in yolks, even after laying, for instance the use of chemicals such as polysorbate-80 as an agent, which weakens the protein bonds in the structural stabilization of egg lipoprotein (Paraskevopoulou \& Kiosseoglou, 1995).

Consumer behaviour and preferences are frequently influenced by the marketing strategies of food producers and retailers. Although knowledge of the details of egg production systems (hen genotype, nutrition, housing, etc.) is poor among consumers, they are willing to pay more for eggs produced in systems 
bearing trendy names related to healthier, safer alimentation (designer eggs, enriched eggs) or traditional farming systems (organic, free-range, barn, etc.) (Parrott, 2004). Mesias et al. (2011) showed that consumers prefer table eggs produced in alternative farming systems, because they meet their beliefs about animal welfare or because they think that such eggs are less rich in cholesterol and total fat. In brief, such products are considered healthier, safer and more ethically produced, compared with those originating from conventional farming systems.

Finally, the question arises: In order to provide well-balanced eggs for consumer needs - so-called functional or designer eggs - what feeding and rearing systems should be used for laying hens to better manage all the influential factors? The present paper aims to briefly present the findings on the nutritional and dietetic quality (chemical composition, cholesterol, gross energy) of the eggs produced within two EUapproved alternative housing systems (improved cages and free range), compared with the conventional system (cage), during the peak production of laying hens, as part of a greater project that aims to assess the influence of fowl welfare-friendly housing systems on the quality of poultry meat and table eggs.

\section{Materials and Methods}

The biological material consisted of eggs produced by 1200 Lohmann Brown Classic $®$ (Lohmann Tierzucht $\mathrm{GmbH}$, Germany) laying hens, aged 27 weeks, and were randomly allocated to three groups, differentiated through accommodation and facilities: B-Control group: 400 hens reared in conventional cage batteries (500 $\mathrm{cm}^{2} /$ hen, banned from 1 January 2012); improved cages (IC) group: 400 hens accommodated in furnished cages $\left(800 \mathrm{~cm}^{2} /\right.$ hen, perches and nests inside the cage) and free range (FR) group: 400 hens, reared on deep litter, with access to an outer paddock (density of 9 hens $/ \mathrm{m}^{2}$ ). The technology used in the IC and FR groups complied with the welfare requirements stipulated in Council dir. 74/1999/EEC (European Union Council, 1999). All experimentations were scrutinized in terms of bioethics principles. Therefore no animals suffered injury, abuse or maltreatment during the trial, and their needs were fulfilled in accordance with the technological guide published by the hybrid producer (Lohmann Tierzucht $\mathrm{GmbH}$, 2012).

All hens were fed an adult layer mixed-feed diet, based on corn-wheat and soybean meal (metabolizable energy $=11.64 \mathrm{MJ}$; crude protein $=17.8 \mathrm{~g} / 100 \mathrm{~g}$ ), in order to avoid the influence of certain feed nutrients on the ultimate nutritional value of the eggs, knowing that the quality of lipids in animal products varies in relation to the feed composition (Leeson \& Summers, 2005).

At the end of the 27th week of the hens' life, 250 eggs were sampled from each group, in order to run chemical investigations. The eggs were broken, the yolks and albumens were separated and then mixed separately. One litre was sampled and labelled from each egg as compound fresh mixture. The remnants of yolks and albumens were mixed together again to form a melange, which served as biological material (one litre of fresh melange) for whole egg composition investigation.

The three samples (yolk, albumen and melange) were weighed and dehydrated at $60^{\circ} \mathrm{C}$ in a forced airflow incubator, Memmert IFE 500 model, for 48 hours. On the resultant powder, analyses were performed to identify and quantify the values for water, dry matter, ash, proteins (total nitrogen matters), lipids, nitrogen free extract, gross energy and cholesterol (20 repetitions for each parameter). Weighing was done on a Shimadzu UX4200H scale (for values above $320 \mathrm{~g}$, precision $0.01 \mathrm{~g}$ ) and on a Denver Instruments Pinnacle 214 scale (for values below $210 \mathrm{~g}$, precision $0.0001 \mathrm{~g}$ ). Most of the parameters were expressed in terms of $100 \mathrm{~g}$ edible portion, while some, such as cholesterol and gross energy, were recalculated per one table egg $(60 \mathrm{~g})$, in order to better depict the nutritional involvement in human beings. When recalculated, it was assumed that of $60 \mathrm{~g}$ egg mass, mineral shell and shell membranes represented $8.4 \%$. Thus $91.6 \%$ of egg weight was represented by the edible parts (yolk and albumen). Therefore, the values obtained for $100 \mathrm{~g}$ edible portion were adjusted to a $55 \mathrm{~g}$ edible portion to estimate the cholesterol and gross energy value for a $60 \mathrm{~g}$ egg.

The AOAC method no. 925.30 (AOAC, 1990) was used to assess solids (dry matter) in pre-dried eggs by dehydration in a Memmert UFE 700 forced air oven at $100{ }^{\circ} \mathrm{C}$. Water (W) content resulted from the difference, according to the relation: Water $(\%)=100 \%-\mathrm{DM}(\%)$. Crude ash content was assessed via incinerating at $550{ }^{\circ} \mathrm{C}$, in a Super Therm C311 oven after prior combustion with a Bunsen funnel, until samples ceased to smoke, in accordance with AOAC 900.02 specification (AOAC, 1990).

Crude protein (CP) resulted from total nitrogen content assessment via the Kjeldahl method, applied on a Velp Scientifica DK 6 digestion and UDK 7 distillation system, according to AOAC method no. 925.31 (AOAC, 1990). Finally, the total nitrogen content was multiplied by 6.25 , which generated the crude protein content. Total lipids as crude fat (CF) content was determined by AOAC method no 925.32 (AOAC, 1990), using a Velp Scientifica Soxhlet SER 148 extractor. Nitrogen free extract (NFE) was calculated as the difference: NFE (\%) $=100-(\mathrm{W} \%+$ Ash $\%+C P \%+C F \%)(F A O, 2003 b)$. The nutritive value of eggs was evaluated through their gross energy content, using the theoretical relation that is based on the quantity of gross energy spread by the combustion of $1 \mathrm{~g}$ crude protein, crude fat and nitrogen-free extract in 
megajoules (MJ): Gross energy (MJ/100 g) $=0.0182 \mathrm{MJ} \times \% \mathrm{CP}+0.0377 \mathrm{MJ} \times \% \mathrm{CF}+0.0154 \mathrm{MJ} \times \mathrm{N} \mathrm{NFE})$ (FAO, 2003a).

Cholesterol concentration was assessed using the titrimetric method as specified by AOAC 941.09 protocol. According to this method, Cholesterol $(\mathrm{mg})=0.55+0.688 \times \mathrm{mL} \mathrm{0.2N} \mathrm{Na} \mathrm{S}_{2} \mathrm{O}_{3}(\mathrm{AOAC}, 1990)$.

Collected data were subjected to statistical computation, using the ANOVA one-way algorithm included in MsExcel, to calculate the descriptive statistics (mean, standard error) and find out whether there were significant differences and upgraded with PostHoc Daniel's XL Toolbox version 4.01 (http://xltoolbox.sf.net), to identify the differences.

\section{Results and Discussions}

The analytical findings on the yolks are presented in Table 1, while those on the albumen are given in Table 2. The water content in egg yolks varied between $55.7 \pm 0.74 \%$ (control conventional battery) and 57.3 $\pm 1.49 \%$ (free-range farming system). The differences ( $P<0.05, \mathrm{~B}$ vs. FR and $P<0.001$, B vs. FR) suggest that compared with cage husbandry systems, the outdoor environment influenced the content of water in laid eggs, increasing it, thus decreasing the total dry matter content in yolk.

No significance differences occurred in the ash content in the yolks among the groups. Also, total CP content was similar between groups (13.6 $\pm 0.86 \%$ for free range to $13.7 \pm 0.69 \%$ for conventional cages). The slight differences were not significant, and could be regarded as not related to the husbandry system, but to individual variations of hens.

Table 1 Means $( \pm$ SD) for the chemical composition and dietetic quality (cholesterol, gross energy) of yolks from table eggs produced in conventional batteries, improved cages and free-range systems

\begin{tabular}{|c|c|c|c|c|c|c|}
\hline \multirow{2}{*}{$\begin{array}{l}\text { Quality } \\
\text { parameters }\end{array}$} & \multicolumn{3}{|c|}{ Housing systems } & \multicolumn{3}{|c|}{ ANOVA computation and analysis } \\
\hline & Battery & $\begin{array}{c}\text { Improved } \\
\text { cages }\end{array}$ & Free range & $\begin{array}{c}\text { Compared } \\
\text { groups }\end{array}$ & $P$ value & Significance \\
\hline $\begin{array}{l}\text { Water } \\
(\%)\end{array}$ & $55.7^{\mathrm{a}} \pm 0.74$ & $56.2^{\mathrm{a}} \pm 1.51$ & $57.3^{\mathrm{db}} \pm 1.49$ & $\begin{array}{l}\text { B vs. IC } \\
\text { B vs. FR } \\
\text { IC vs. FR }\end{array}$ & $\begin{array}{l}0.20720 \\
0.00017 \\
0.03054\end{array}$ & 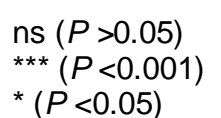 \\
\hline $\begin{array}{l}\text { Dry matter } \\
(\%)\end{array}$ & $44.3^{\mathrm{a}} \pm 0.74$ & $43.8^{\mathrm{a}} \pm 1.51$ & $42.7^{\mathrm{db}} \pm 1.49$ & $\begin{array}{l}\text { B vs. IC } \\
\text { B vs. FR } \\
\text { IC vs. FR }\end{array}$ & $\begin{array}{l}0.20720 \\
0.00017 \\
0.03054\end{array}$ & $\begin{array}{l}\mathrm{ns}(P>0.05) \\
\star * \star \\
*(P<0.001) \\
*(P<0.05)\end{array}$ \\
\hline $\begin{array}{l}\text { Ash } \\
(\%)\end{array}$ & $1.29 \pm 0.28$ & $1.22 \pm 0.26$ & $1.19 \pm 0.31$ & $\begin{array}{l}\text { B vs. IC } \\
\text { IC vs. FR } \\
\text { B vs. FR }\end{array}$ & $\begin{array}{l}0.41376 \\
0.28689 \\
0.74198\end{array}$ & $\begin{array}{l}\text { ns }(P>0.05) \\
\text { ns }(P>0.05) \\
\text { ns }(P>0.05)\end{array}$ \\
\hline $\begin{array}{l}\text { Crude protein } \\
(\%)\end{array}$ & $13.7 \pm 0.69$ & $13.6 \pm 0.78$ & $13.6 \pm 0.86$ & $\begin{array}{l}\text { B vs. IC } \\
\text { B vs. FR } \\
\text { IC vs. FR }\end{array}$ & $\begin{array}{l}0.54941 \\
0.54599 \\
0.96874\end{array}$ & $\begin{array}{l}\text { ns }(P>0.05) \\
\text { ns }(P>0.05) \\
\text { ns }(P>0.05)\end{array}$ \\
\hline Lipids (\%) & $28.4^{\mathrm{a}} \pm 1.61$ & $28.0^{\mathrm{ab}} \pm 2.22$ & $26.8^{\mathrm{b}} \pm 2.14$ & $\begin{array}{l}\text { B vs. IC } \\
\text { B vs. FR } \\
\text { IC vs. FR }\end{array}$ & $\begin{array}{l}0.50146 \\
0.01443 \\
0.11323\end{array}$ & $\begin{array}{l}\text { ns }(P>0.05) \\
{ }^{*}(P<0.05) \\
\text { ns }(P>0.05)\end{array}$ \\
\hline $\begin{array}{l}\text { Nitrogen free } \\
\text { extract (\%) }\end{array}$ & $0.90 \pm 0.14$ & $1.05 \pm 0.34$ & $1.14 \pm 0.65$ & $\begin{array}{l}\text { B vs. IC } \\
\text { B vs. FR } \\
\text { IC vs. FR }\end{array}$ & $\begin{array}{l}0.08542 \\
0.11422 \\
0.56150\end{array}$ & $\begin{array}{l}\text { ns }(P>0.05) \\
\text { ns }(P>0.05) \\
\text { ns }(P>0.05)\end{array}$ \\
\hline $\begin{array}{l}\text { Gross energy } \\
(\mathrm{MJ} / 100 \mathrm{~g})\end{array}$ & $1.33^{\mathrm{a}} \pm 0.05$ & $1.32^{\mathrm{ac}} \pm 0.07$ & $1.28^{\mathrm{c}} \pm 0.06$ & $\begin{array}{l}\text { B vs. IC } \\
\text { B vs. FR } \\
\text { IC vs. FR }\end{array}$ & $\begin{array}{l}0.42705 \\
0.00618 \\
0.08696\end{array}$ & $\begin{array}{l}\mathrm{ns}(P>0.05) \\
* *(P<0.01) \\
\text { ns }(P>0.05)\end{array}$ \\
\hline $\begin{array}{l}\text { Cholesterol } \\
(\mu \mathrm{g} / 100 \mathrm{~g})\end{array}$ & $957^{\text {bd }} \pm 28.7$ & $931^{a} \pm 32.8$ & $920^{\mathrm{a}} \pm 35.4$ & $\begin{array}{l}\text { B vs. IC } \\
\text { B vs. FR } \\
\text { IC vs. FR }\end{array}$ & $\begin{array}{l}0.01017 \\
0.00066 \\
0.29529\end{array}$ & $\begin{array}{l}*(P<0.05) \\
\star * \star \\
\text { ns }(P<0.001) \\
\text { ns }(P 0.05)\end{array}$ \\
\hline
\end{tabular}

ANOVA within rows, between groups for different superscripts, one by one comparison: ns: not significant; ${ }^{\text {ab }}$ significant, ${ }^{*}(P<0.05)$; distinguished significant $={ }^{\text {ac }}$, ${ }^{\star *}(P<0.01)$; highly significant $={ }_{\star \star \star \star}(P<0.001)$.

The yolk of the eggs produced in cage-free technology were $5.73 \%$ (1.54 percentage points $(\mathrm{pp})$ ) poorer in total lipids (CF), compared with conventionally produced eggs $(B=26.8 \pm 2.14 \%$ vs. FR $=28.4 \pm$ $1.61 \%)$, the difference being statistically significant. Dissimilar lipid contents induced different gross energy 
values/100 g yolk portion $(P<0.01)$, viz. higher gross energy values $(1.33 \pm 0.05 \mathrm{MJ})$ in eggs from standard cages and $1.32 \pm 0.07 \mathrm{MJ}$ in eggs from IC, and less $(1.28 \pm 0.06 \mathrm{MJ})$ in yolk produced in the FR.

Owing to a lower total lipid content in yolk, cholesterol concentration was lower $(P<0.05)$ in free-range yolks $(920 \pm 35.4 \mu \mathrm{g} / 100 \mathrm{~g})$ compared with that from the IC system $(931 \pm 32.8 \mu \mathrm{g} / 100 \mathrm{~g})$. Higher differences occurred when comparing FR and B yolks $(P<0.001)$. A percentage difference of $4.1 \%$ in favour of conventionally produced eggs was recorded, viz. $958 \pm 28.7 \mu \mathrm{g}$ cholesterol/100 g vs. $920 \pm 35.4 \mu \mathrm{g} / 100 \mathrm{~g}$. From the present findings, it is clear that housing and farming system affected nutritive values, indicated by differences in gross energy and cholesterol levels.

However, the subject of the influence of housing system on the dietetic and nutritional value of yolks is still controversial because contradictory results have been reported. Data published by Wang et al. (2009) support our results: In eggs produced in cages (conventional system) versus those produced outdoors (free range), the yolk cholesterol concentration was $19.4 \%$ higher $(10.32 \pm 0.48 \mathrm{mg} / \mathrm{g}$ vs. $8.64 \pm 0.40 \mathrm{mg} / \mathrm{g}, P$ $<0.05)$.

Under free-range conditions the cholesterol concentration of eggs (13.8 and $14.0 \mathrm{mg} / \mathrm{g}$ of yolk) was lower than for eggs laid by deep litter hens (14.0 - $14.5 \mathrm{mg} / \mathrm{g}$ of yolk) (Krawczyk \& Gornowicz, 2010). In a study that used Greenleg partridge as experimental material, it was found that organic husbandry induced the lowest cholesterol content in yolk, compared with backyard traditional systems and the conventional deep litter system (Krawczyk, 2009). On the other hand, certain results are contradictory to our findings, for instance, in the deep litter system (alternative farming system, precursor of the free range), yolk cholesterol concentration was higher $(P<0.01)$ in comparison with the cage system of laying hens (Pistekova et al., 2006). Applied housing system altered yolk and egg cholesterol concentration $(P<0.01)$, which was found to be lower in the IC system (12.5 mg/g yolk and $211.2 \mathrm{mg} / \mathrm{egg}$, respectively) and higher in the deep litter accommodation system (14.1 mg/g yolk and $242.6 \mathrm{mg} / \mathrm{egg}$, respectively). (Zemkova et al., 2007). Also, in commercial hybrid eggs(ISA Brown), yolk cholesterol concentration was slightly higher for the free-range system $(11.8 \pm 0.30 \mathrm{mg} / \mathrm{g})$ compared with the cage production system $(11.4 \pm 0.49 \mathrm{mg} / \mathrm{g})$. The same

Table 2 Means ( \pm SD) for chemical composition and dietetic quality (cholesterol, gross energy) of albumen from table eggs produced in conventional batteries, improved cages and free-range systems

\begin{tabular}{|c|c|c|c|c|c|c|}
\hline \multirow{2}{*}{$\begin{array}{l}\text { Quality } \\
\text { parameters }\end{array}$} & \multicolumn{3}{|c|}{ Housing systems } & \multicolumn{3}{|c|}{ ANOVA computation and analysis } \\
\hline & Battery & $\begin{array}{c}\text { Improved } \\
\text { cages }\end{array}$ & Free range & $\begin{array}{c}\text { Compared } \\
\text { groups }\end{array}$ & $P$ value & Significance \\
\hline $\begin{array}{l}\text { Water } \\
(\%)\end{array}$ & $87.9 \pm 0.59$ & $88.0 \pm 0.64$ & $88.1 \pm 0.64$ & $\begin{array}{l}\text { B vs. IC } \\
\text { B vs. FR } \\
\text { IC vs. FR }\end{array}$ & $\begin{array}{l}0.56906 \\
0.34183 \\
0.70942 \\
\end{array}$ & $\begin{array}{l}\text { ns }(P>0.05) \\
\text { ns }(P>0.05) \\
\text { ns }(P>0.05)\end{array}$ \\
\hline $\begin{array}{l}\text { Dry matter } \\
(\%)\end{array}$ & $12.1 \pm 0.59$ & $12.0 \pm 0.64$ & $11.9 \pm 0.60$ & $\begin{array}{l}\text { B vs. IC } \\
\text { B vs. FR } \\
\text { IC vs. FR } \\
\end{array}$ & $\begin{array}{l}0.56906 \\
0.34183 \\
0.70942 \\
\end{array}$ & $\begin{array}{l}\text { ns }(P>0.05) \\
\text { ns }(P>0.05) \\
\text { ns }(P>0.05)\end{array}$ \\
\hline $\begin{array}{l}\text { Ash } \\
(\%)\end{array}$ & $0.66^{\mathrm{a}} \pm 0.06$ & $0.61^{\mathrm{ca}} \pm 0.05$ & $0.56^{d d} \pm 0.03$ & $\begin{array}{l}\text { B vs. IC } \\
\text { B vs. FR } \\
\text { IC vs. FR } \\
\end{array}$ & $\begin{array}{l}0.00392 \\
0.00005 \\
0.00034 \\
\end{array}$ & $\begin{array}{l}* \star(P<0.01) \\
\star \star \star \\
\star P<0.001) \\
\star \star \star \\
(P<0.001)\end{array}$ \\
\hline $\begin{array}{l}\text { Crude protein } \\
(\%)\end{array}$ & $10.98 \pm 0.59$ & $11.01 \pm 0.59$ & $11.04 \pm 0.63$ & $\begin{array}{l}\text { B vs. IC } \\
\text { B vs. FR } \\
\text { IC vs. FR }\end{array}$ & $\begin{array}{l}0.86727 \\
0.73191 \\
0.85747 \\
\end{array}$ & $\begin{array}{l}\text { ns }(P>0.05) \\
\text { ns }(P>0.05) \\
\text { ns }(P>0.05)\end{array}$ \\
\hline Lipids (\%) & $0.09 \pm 0.02$ & $0.08 \pm 0.02$ & $0.08 \pm 0.02$ & $\begin{array}{l}\text { B vs. IC } \\
\text { B vs. FR } \\
\text { IC vs. FR }\end{array}$ & $\begin{array}{l}0.92955 \\
0.10038 \\
0.12051 \\
\end{array}$ & $\begin{array}{l}\text { ns }(P>0.05) \\
\text { ns }(P>0.05) \\
\text { ns }(P>0.05)\end{array}$ \\
\hline $\begin{array}{l}\text { Nitrogen free } \\
\text { extract (\%) }\end{array}$ & $0.37^{\mathrm{a}} \pm 0.08$ & $0.28^{\mathrm{ca}} \pm 0.10$ & $0.19^{\mathrm{db}} \pm 0.11$ & $\begin{array}{l}\text { B vs. IC } \\
\text { B vs. FR } \\
\text { IC vs. FR } \\
\end{array}$ & $\begin{array}{l}0.00363 \\
0.00005 \\
0.01062 \\
\end{array}$ & $\begin{array}{l}* \star(P<0.01) \\
\star \star \star \\
*(P<0.001) \\
*(P<0.05)\end{array}$ \\
\hline $\begin{array}{l}\text { Gross energy } \\
(\mathrm{MJ} / 100 \mathrm{~g})\end{array}$ & $0.21 \pm 0.009$ & $0.21 \pm 0.010$ & $0.21 \pm 0.010$ & $\begin{array}{l}\text { B vs. IC } \\
\text { B vs. FR } \\
\text { IC vs. FR } \\
\end{array}$ & $\begin{array}{l}0.06343 \\
0.36536 \\
0.73822 \\
\end{array}$ & $\begin{array}{l}\text { ns }(P>0.05) \\
\text { ns }(P>0.05) \\
\text { ns }(P>0.05)\end{array}$ \\
\hline $\begin{array}{l}\text { Cholesterol } \\
(\mu \mathrm{g} / 100 \mathrm{~g})\end{array}$ & ND & ND & ND & - & - & - \\
\hline
\end{tabular}

ANOVA within rows, between groups for different superscripts, one by one comparison: ns: not significant; significant $={ }^{\mathrm{ab}},{ }^{*}(P<0.05)$; distinguished significant $={ }^{\mathrm{ac}},{ }^{\star \star}(P<0.01)$; highly significant $={ }^{\mathrm{ad}}$, ${ }^{\star \star *}(P<0.001)$. 
situation occurred for a local Slovenian strain of hens (Styrian): The outdoor production system lead to a higher concentration of cholesterol in yolks, $13.6 \pm 0.22 \mathrm{mg} / \mathrm{g}$, than in a cage system, $13.1 \pm 0.43 \mathrm{mg} / \mathrm{g}$ (Simcic et al., 2009).

Considering the chemical composition of albumen (Table 2): The concentrations were similar among the groups. Therefore the housing system did not significantly influence contents in water, dry matter and other macronutrients such as crude protein and lipids. However, other researchers reported a higher protein content in the albumin from the backyard system of rearing Greenleg partridges (Krawczyk, 2009).

Certain micronutrients, however, were affected by the housing system that was practised. Albumen minerals differed greatly and significantly between groups: the lowest content of crude ash $(0.56 \pm 0.03 \%)$ occurred in FR eggs, compared with the richest $(0.66 \pm 0.06 \%)$ in conventional cage-produced eggs. The same situation was observed for the NFE content. However, the chemical composition of albumen was within normal limits for all nutrients. Cholesterol was undetectable, as expected, and low gross energy values were calculated per $100 \mathrm{~g}$ edible portion of albumen $(0.21 \mathrm{MJ})$.

A small difference in dry matter content was detected between groups and protein proportions of the albumen from all groups were almost similar (10.98 to 1.04\%), while lipids were detected at very low concentration ( $0.08 \pm 0.02 \%$ in IC and FR eggs; $0.09 \pm 0.02 \%$ in B eggs), hence the low energy content $(0.21 \mathrm{MJ} / 100 \mathrm{~g}$ albumen). These facts reaffirm the exceptional dietetic features of egg white, which is a reservoir of high-quality proteins, packaged with a small or no amount of compounds that are not beneficial to consumer health, such as cardiovascular diseases.

The chemical content of the whole fresh eggs (mix of edible parts, yolk and albumen) was assessed, because in human nutrition whole eggs are mostly used, consumed as such, or included as a processed food ingredient in the form of powdered white and yolk mixture. The results are presented in Table 3.

The chemical composition of the yolk influenced the whole egg constituent dynamics and differentiations between the three groups. The water content varied between $75.0 \pm 0.12 \%$ (conventional cage eggs) and $75.8 \pm 0.22 \%$ (free-range eggs). Highly significant differences occurred for this trait in all three comparisons. Proportionally, dry matter content varied conversely, being richer in the eggs from cages, compared with cage free $(P<0.001)$. Percentage of minerals was slightly lower in the edible compartments of free-range eggs, compared with those laid in conventional cages $(-12 \%)$ and not different enough from those issued from improved cages to pass a statistic threshold.

The protein content was similar between groups (12.03\% - 12.07\%), with no significant differences. Minelli et al. (2007) have reported different values for crude protein, in favour of organically produced eggs, $(17.1 \%$ vs. $16.7 \%)$ compared with those from the conventional system. Lipid content varied significantly $(P$ $<0.05$ ) from $10.78 \pm 0.87 \%$ (FR eggs) to $11.4 \pm 0.65 \%$ (B eggs), while IC eggs presented intermediate values (11.23 $\pm 0.9 \%$ crude fat). Therefore, gross energy content was slightly higher in eggs from conventional battery cages $(0.66 \pm 3.37 \mathrm{MJ} / 100 \mathrm{~g}$ or $0.36 \pm 0.007 \mathrm{MJ} / \mathrm{egg}$ of $60 \mathrm{~g})$, compared with those produced in the improved cage system $(0.65 \pm 0.023 \mathrm{MJ} / 100 \mathrm{~g}$ or $0.36 \pm 0.013 \mathrm{MJ} / \mathrm{egg}$ of $60 \mathrm{~g})$ and the eggs laid under freerange farming conditions $(0.63 \pm 0.022 \mathrm{MJ} / 100 \mathrm{~g}$ or $0.35 \pm 0.012 \mathrm{MJ} / \mathrm{egg}$ of $60 \mathrm{~g})$. The differences were found to be highly significant (B vs. FR, $P<0.001 ;+3.71 \%$ more gross energy in conventional cages eggs) or significant (IC vs. FR, $P<0.05$; improved cages eggs were $2.72 \%$ richer in gross energy).

The differences in cholesterol content was similar to that measured for gross energy, with values varying from $202 \pm 7.79 \mu \mathrm{g} / \mathrm{egg}$ of $60 \mathrm{~g}$ in free-range system to $211 \pm 6.31 \mu \mathrm{g} / \mathrm{egg}$ of $60 \mathrm{~g}$ in conventional cages, while that from eggs from the improved cages was $205 \pm 7.22 \mu \mathrm{g}$ cholesterol per one $60 \mathrm{~g}$ egg. The differences between FR and B values were highly significant, while the other comparisons (B vs. IC and IC vs. FR) showed $(P<0.05)$ a significance threshold. Studies conducted by Minelli et al. (2007) support our findings, stating that conventionally produced eggs are richer in cholesterol than organic ones, while Anderson (2011) and Shapira (2011) found that housing environment did not affect the inner cholesterol content of the eggs significantly, even if the free-range ones were slightly richer in this nutrient. Nevertheless, any excessive content of lipids and cholesterol in free-range eggs could be nutritionally counterbalanced by the lipid quality in such eggs, for example higher levels of n-3 PUFA in the yolks of free-range eggs, compared with deep litter ones $(P<0.05)$ (Krawczyk \& Gornowicz, 2010).

According to the acquired data, it could be supposed that the reduced mobility of hens in cages on one hand, and higher mobility, as well as the need for adaptation to outdoor environmental conditions (including thermoregulation mechanisms), of the free-range hens on the other hand, influenced energy and nutrients uptake from compound feed and their metabolising in fowl organism, then the transfer of certain excessive nutrients, for example lipids, from the bloodstream to eggs. Thus, the eggs produced in cages, no matter whether conventional or furnished, were higher in energy, consequently less nutritious, than those laid in free-range systems. 
Table 3 Means $( \pm$ SD) for chemical composition and dietetic quality (cholesterol, gross energy) of whole edible table eggs produced in conventional batteries, improved cages and free-range systems

\begin{tabular}{|c|c|c|c|c|c|c|}
\hline \multirow{2}{*}{$\begin{array}{l}\text { Quality } \\
\text { Parameters }\end{array}$} & \multicolumn{3}{|c|}{ Housing systems } & \multicolumn{3}{|c|}{ ANOVA PostHoc (Tukey) } \\
\hline & Battery & Improved cages & Free range & $\begin{array}{c}\text { Compared } \\
\text { groups }\end{array}$ & $P$ value & Significance \\
\hline \multirow{3}{*}{$\begin{array}{l}\text { Water } \\
(\%)\end{array}$} & \multirow{3}{*}{$75.0^{\mathrm{aa}} \pm 0.12$} & \multirow{3}{*}{$75.3^{d a} \pm 0.25$} & \multirow{3}{*}{$75.8^{d d} \pm 0.22$} & B vs. IC & 0.00001 & $\star \star \star ~(P<0.001)$ \\
\hline & & & & B vs. FR & 0.00004 & $\star \star \star ~(P<0.001)$ \\
\hline & & & & IC vs. FR & 0.00001 & $\star \star \star ~(P<0.001)$ \\
\hline \multirow{3}{*}{ Dry matter (\%) } & \multirow{3}{*}{$25.0^{\mathrm{aa}} \pm 0.12$} & \multirow{3}{*}{$24.7^{d a} \pm 0.25$} & \multirow{3}{*}{$24.2^{\mathrm{dd}} \pm 0.22$} & B vs. IC & 0.00001 & $\star \star \star \star ~(P<0.001)$ \\
\hline & & & & B vs. FR & 0.00004 & $\star \star \star ~(P<0.001)$ \\
\hline & & & & IC vs. FR & 0.00001 & $\star \star \star ~(P<0.001)$ \\
\hline \multirow{3}{*}{$\begin{array}{l}\text { Ash } \\
\text { (\%) }\end{array}$} & \multirow{3}{*}{$0.91 \pm 0.14$} & \multirow{3}{*}{$0.85 \pm 0.14$} & \multirow{3}{*}{$0.81 \pm 0.14$} & B vs. IC & 0.17482 & ns $(P>0.05)$ \\
\hline & & & & B vs. FR & 0.06839 & ns $(P>0.05)$ \\
\hline & & & & IC vs. FR & 0.05454 & ns $(P>0.05)$ \\
\hline \multirow{3}{*}{$\begin{array}{l}\text { Crude protein } \\
(\%)\end{array}$} & \multirow{3}{*}{$12.07 \pm 0.63$} & \multirow{3}{*}{$12.03 \pm 0.67$} & \multirow{3}{*}{$12.06 \pm 0.72$} & B vs. IC & 0.06109 & ns $(P>0.05)$ \\
\hline & & & & B vs. FR & 0.05418 & ns $(P>0.05)$ \\
\hline & & & & IC vs. FR & 0.05983 & $\mathrm{~ns}(P>0.05)$ \\
\hline \multirow{3}{*}{ Lipids (\%) } & \multirow{3}{*}{$11.40^{\mathrm{a}} \pm 0.65$} & \multirow{3}{*}{$11.23^{\mathrm{ab}} \pm 0.90$} & \multirow{3}{*}{$10.78^{b} \pm 0.87$} & B vs. IC & 0.50618 & ns $(P>0.05)$ \\
\hline & & & & B vs. FR & 0.01482 & $\star(P<0.05)$ \\
\hline & & & & IC vs. FR & 0.11306 & ns $(P>0.05)$ \\
\hline \multirow{3}{*}{$\begin{array}{l}\text { Nitrogen free } \\
\text { extract } \\
(\%) \\
\end{array}$} & \multirow{3}{*}{$0.58 \pm 0.07$} & \multirow{3}{*}{$0.59 \pm 0.15$} & \multirow{3}{*}{$0.60 \pm 0.25$} & B vs. IC & 0.89191 & ns $(P>0.05)$ \\
\hline & & & & B vs. FR & 0.79976 & ns $(P>0.05)$ \\
\hline & & & & IC vs. FR & 0.88462 & ns $(P>0.05)$ \\
\hline \multirow{3}{*}{$\begin{array}{l}\text { Gross energy } \\
(\mathrm{MJ} / 100 \mathrm{~g})\end{array}$} & \multirow{3}{*}{$0.66^{a} \pm 0.014$} & \multirow{3}{*}{$0.65^{a} \pm 0.023$} & & B vs. IC & 0.27161 & ns $(P>0.05)$ \\
\hline & & & $0.63^{\mathrm{db}} \pm 0.022$ & B vs. FR & 0.00033 & $\star \star \star ~(P<0.001)$ \\
\hline & & & & IC vs. FR & 0.02919 & $*(P<0.05)$ \\
\hline Gross eneray & & & & B vs. IC & 0.27161 & ns $(P>0.05)$ \\
\hline $\begin{array}{l}\text { Gross energy } \\
(\mathrm{MJ} / \mathrm{eqa} \text { of } 60 \mathrm{q})\end{array}$ & $0.36^{\mathrm{a}} \pm 0.007$ & $0.36^{\mathrm{a}} \pm 0.013$ & $0.35^{\mathrm{db}} \pm 0.012$ & B vs. FR & 0.00033 & $\star \star \star ~(P<0.001)$ \\
\hline & & & & IC vs. FR & 0.02919 & $\star(P<0.05)$ \\
\hline & & & & B vs. IC & 0.01017 & $*(P<0.05)$ \\
\hline cholesterol & $383^{a} \pm 11.47$ & $373^{\mathrm{ba}} \pm 13.12$ & $368^{\mathrm{db}} \pm 14.16$ & B vs. FR & 0.00066 & $\star \star \star * ~(P<0.001)$ \\
\hline & & & & IC vs. FR & 0.02563 & $*(P<0.05)$ \\
\hline & & & & B vs. IC & 0.01017 & $*(P<0.05)$ \\
\hline ( $\mathrm{uq} / \mathrm{eqg}$ of $60 \mathrm{q})$ & $211^{a} \pm 6.31$ & $205^{\mathrm{ba}} \pm 7.22$ & $202^{\mathrm{db}} \pm 7.79$ & B vs. FR & 0.00066 & $\star \star \star * ~(P<0.001)$ \\
\hline & & & & IC vs. FR & 0.02563 & * $(P<0.05)$ \\
\hline
\end{tabular}

ANOVA within rows, between groups for different superscripts, one by one comparison: ns: not significant; significant $={ }^{\mathrm{ab}}, *(P<0.05)$; distinguished significant $={ }^{\mathrm{ac}}, * \star *(P<0.01)$; highly significant $={ }^{\mathrm{ad}}, * \star *(P<0.001)$.

It is known that the frequent consumption of animal products, correlated with unhealthy dietary habits and a passive lifestyle, could lead to the contraction of certain so-called civilisation diseases, namely nutritional and metabolic syndromes in human consumers (Christophersen \& Haug, 2011). Therefore further investigations into the quality of lipids in eggs and meat (especially the $\omega-3: \omega-6$ fatty acid ratio) could indicate whether the use of a certain farming system (accommodation, fowl welfare level, feeding, microclimate management, etc.) could influence the nutritive value of poultry products.

It would be interesting to use more eggs as biological material in order to increase the confidence degree of statistical processing. The research is ongoing in order to assess the chemical composition and nutritional value of these products throughout the entire productive period of a commercial laying hen (20 72 weeks).

\section{Conclusions}

Most chemical components of the eggs produced in improved cages and free-range systems did not vary among the samples, except for the lipids and water value. All edible egg parts (whites, yolks) and even whole fresh eggs contained less gross energy and cholesterol in the samples from free-range production systems, compared with those produced in cages. Based on statistical analysis, it could be stated that the husbandry system for laying hens significantly affects water and total solids contents, and lipid, cholesterol and gross energy values of the eggs. Under similar conditions of genotype used and feeding, the nutritive value of eggs was improved by free-range rearing technology, while conventionally produced eggs proved richer in energy and fats, thus less nutritious. In depth investigations into the lipid profile of table eggs could 
enlighten more aspects related to nutritional quality, especially the ratio between saturated, monounsaturated and polyunsaturated fatty acids, which affects the health status of consumers.

\section{Acknowledgments}

The authors wish to thank the Romanian Executive Unit for Financing in Higher Education, Research, Development and Innovation (www.uefiscdi.ro), which supported these investigations through the research contract P.N.C.D.I. II - Human Resources - Postdoctoral projects no. 508/2010-2012. Thanks also to the University of Agricultural Sciences and Veterinary Medicine of lași, Romania (www.uaiasi.ro), which provided funds for developing research through the internal competition for young researchers 2013-2015, contract no. 5528/2013.

\section{References}

Aguiar, A.P.S., Contreras-Castillo, C.J., Baggio, S.R. \& Vicente, E., 2008. Meat quality of broilers from different rearing systems. Ital. J. Food Sci. 20, 213-223.

Akbarian, A., Golian, A., Ahmadi, A.S. \& Moravej, H., 2011. Effects of ginger root (Zingiber officinale) on egg yolk cholesterol, antioxidant status and performance of laying hens. J. Appl. Anim. Res. 39, 19-21.

Anderson, K.E., 2011. Comparison of fatty acid, cholesterol, and vitamin A and E composition in eggs from hens housed in conventional cage and range production facilities. Poult. Sci. 90, 1600-1608.

AOAC, 1990. Official methods of analysis, $13^{\text {th }}$ ed. Food composition, Additives, Natural contaminants Eggs and eggs products (chapter 24). Association of Official Analytical Chemists, Inc. Arlington, Virginia, USA. $1018 \mathrm{pp}$.

Aydin, R. \& Dogan, I., 2010. Fatty acid profile and cholesterol content of egg yolk from chickens fed diets supplemented with purslane (Portulaca oleracea L.). J. Sci. Food Agric. 90, 1759-1763.

Azeke, M.A. \& Ekpo, K.E., 2009. Egg yolk cholesterol lowering effects of garlic and tea. J. Med. Plants Res. 3, 1113-1117.

Basmacioğlu, H., Cabuk, M., Unal, K., Ozkan, K., Akkan, S. \& Yalcin, H., 2003. Effects of dietary fish oil and flax seed on cholesterol and fatty acid composition of egg yolk and blood parameters of laying hens. S. Afr. J. Anim. Sci. 33, 266-273.

Baumgartner, J., Koncekova, Z., Benkova, J., Peskovicova, D., Simenovova, J. \& Csuka, J., 2008. Changes in egg quality traits associated with long-term selection for lower yolk cholesterol content in Japanese quail. Czech J. Anim. Sci. 53, 119-127.

Bessei, W., 2010. Behaviour of laying hens in small group systems in the view of animal welfare. Arch. Geflugelkd. 74, 6-12.

Blokhuis, H.J., Van Niekerk, T.F., Bessei, W., Elson, A., Guemene, D., Kjaer, J.B., Levrino, G.A.M., Nicol, C.J., Tauson, R., Weeks, C.A. \& De Weerd, H.A.V., 2007. The LayWel project: welfare implications of changes in production systems for laying hens. Wrld Poult. Sci. J. 63, 101-114.

Bolukbasi, S.C., Erhan, M.K. \& Kaynar, O., 2008. The effect of feeding thyme, sage and rosemary oil on laying hen performance, cholesterol and some proteins ratio of egg yolk and Escherichia coli count in feces. Arch. Geflugelkd. 72, 231-237.

Bourre, J.M. \& Galea, F., 2006. An important source of omega-3 fatty acids, vitamins D and E, carotenoids, iodine and selenium: A new natural multi-enriched egg. J. Nutr. Health Aging 10, 371-376.

Celik, L., Kutlu, H.R., Sahan, Z., Kiraz, A.B., Serbester, U., Hesenov, A. \& Tekeli, A., 2011. Dietary inclusion of pumpkin seed oil for a cholesterol low and oleic and linolenic acid rich egg production in layer hens. Rev. Med. Vet., 162, 126-132.

Cherian, G., Holsonbake, T.B. \& Goeger, M.P., 2002. Fatty acid composition and egg components of specialty eggs. Poult. Sci. 81, 30-33.

Christophersen, O.A. \& Haug, A., 2011. Animal products, diseases and drugs: a plea for better integration between agricultural sciences, human nutrition and human pharmacology. Lipids Health Dis. 10, 38.

Elkin, R.G., 2007. Reducing shell egg cholesterol content. II. Review of approaches utilizing non-nutritive dietary factors or pharmacological agents and an examination of emerging strategies. Wrld Poult. Sci. J. $63,5-31$.

European Union Council, 1999. Council Directive 1999/74/EC of 19 July 1999 laying down minimum standards for the protection of laying hens. Official Journal of the European Communities, L203, 5.

FAO, 2003a. Calculation of the energy content of foods - energy conversion factors (chapter 3). In: FAO (ed.) FAO Food Nutrition Paper, Food energy - methods of analysis and conversion factors. Food and Agriculture Organisation of the United Nations, Rome, Italy.

FAO, 2003b. Methods of Food Analysis (chapter 2). Food and Agriculture Organisation of the United Nations, Rome, Italy. 
Han, Y.K., Jin, Y.H., Lee, W.I., Lee, K.T. \& Thacke, P.A., 2010. Influence of lysolecithin on the performance of laying hens, interior and exterior egg quality as well as fat soluble vitamin and cholesterol content in the yolk. J. Anim. Vet. Adv. 9, 2583-2588.

Hidalgo, A., Rossi, M., Clerici, F. \& Ratti, S., 2008. A market study on the quality characteristics of eggs from different housing systems. Food Chem. 106, 1031-1038.

Holt, P.S., Davies, R.H., Dewulf, J., Gast, R.K., Huwe, J.K., Jones, D.R., Waltman, D. \& Willian, K.R., 2011. The impact of different housing systems on egg safety and quality. Poult. Sci. 90, 251-262.

Islam, M.T., Selim, A.S.M., Abu Sayed, M., Khatun, M.A., Siddiqui, M.N., Alam, M.S. \& Hossain, M.A., 2011. Nigella sativa L. supplemented diet decreases egg cholesterol content and suppresses harmful intestinal bacteria in laying hens. J. Anim. Feed Sci. 20, 587-598.

Khan, S.H., Atif, M., Mukhtar, N., Rehman, A. \& Fareed, G., 2011. Effects of supplementation of multienzyme and multi-species probiotic on production performance, egg quality, cholesterol level and immune system in laying hens. J. Appl. Anim. Res. 39, 386-398.

King, S., Hugo, A., De Witt, F.H., Van der Merwe, H.J. \& Fair, M.D., 2012. Effect of dietary fat source on fatty acid profile and lipid oxidation of eggs. S. Afr. J. Anim. Sci. 42 (5, Suppl. 1), 503-506.

Krawczyk, J., 2009. Quality of eggs from Polish native Greenleg Partridge chicken-hens maintained in organic vs. backyard production systems. Anim. Sci. Pap. Rep. 27, 227-235.

Krawczyk, J. \& Gornowicz, E., 2010. Quality of eggs from hens kept in two different free-range systems in comparison with a barn system. Arch. Geflugelkd. 74, 151-157.

Leeson, S. \& Summers, J.D., 2005. Commercial poultry nutrition. $3^{\text {rd }}$ ed., University Books; Ontario; Canada.

Liu, X., Zhao, H.L., Thiessen, S., House, J.D. \& Jones, P.J.H., 2010. Effect of plant sterol-enriched diets on plasma and egg yolk cholesterol concentrations and cholesterol metabolism in laying hens. Poult. Sci., 89, 270-275.

Lohmann Tierzucht, GB, 2012. Lohman Brown Classic Management guides, available online at http://www.lohmanngb.co.uk/lohmann-brown-classic, Accessed July 2012.

Mahmoud, K.Z., Gharaibeh, S.M., Zakaria, H.A. \& Qatramiz, A.M., 2010. Garlic (Allium sativum) supplementation: Influence on egg production, quality, and yolk cholesterol level in layer hens. AsianAust. J. Anim. Sci. 23, 1503-1509.

Mesias, F.J., Martinez-Carrasco, F., Martinez, J.M. \& Gaspar, P., 2011. Functional and organic eggs as an alternative to conventional production: a conjoint analysis of consumers' preferences. J. Sci. Food Agric. 91, 532-538.

Miao, Z.H., Glatz, P.C. \& Ru, Y.J., 2005. Free-range poultry production - A review. Asian-Aust. J. Anim. Sci. $18,113-132$

Minelli, G., Sirri, F., Folegatti, E., Meluzzi, A. \& Franchini, A., 2007. Egg quality traits of laying hens reared in organic and conventional systems. Ital. J. Anim. Sci. 6, 728-730.

Mohiti-Asli, M. \& Zaghari, M., 2010. Does dietary vitamin E or C decrease egg yolk cholesterol? Biol. Trace Elem. Res. 138, 60-68.

Nau, F., Nys, Y., Yamakawa, Y. \& Rehault-Godbert, S., 2010. Nutritional value of the hen egg for humans. Prod. Anim. 23, 225-235.

Paraskevopoulou, A. \& Kiosseoglou, V., 1995. Use of polysorbate-80 to reduce cholesterol in dehydrated egg-yolk. Int. J. Food Sci. Technol. 30, 57-63.

Parrott, P.A.W., 2004. Hen welfare: the consumers' perspective. In: Welfare of the Laying Hen. Ed: Perry, C., $\mathrm{CAB}$ International, Wallingford, United Kingdom. pp. 11-22.

Pistekova, V., Hovorka, M., Vecerek, V., Strakova, E. \& Suchy, P., 2006. The quality comparison of eggs laid by laying hens kept in battery cages and in a deep litter system. Czech J. Anim. Sci. 51, 318-325.

Rizzi, C. \& Chiericato, G.M., 2010. Chemical composition of meat and egg yolk of hybrid and Italian breed hens reared using an organic production system. Poult. Sci. 89, 1239-1251.

Samman, S., Kung, F.P., Carter, L.M., Foster, M.J., Ahmad, Z.I., Phuyal, J.L. \& Petocz, P., 2009. Fatty acid composition of certified organic, conventional and omega-3 eggs. Food Chem. 116, 911-914.

Sarica, M., Sekeroglu, A. \& Karacay, N., 2009. Effect of genotype on fatty acid and cholesterol contents of hen's egg. Asian J. Chem. 21, 511-516.

Shang, H.M., Hu, T.M., Lu, Y.J. \& Wu, H.X., 2010. Effects of inulin on performance, egg quality, gut microflora and serum and yolk cholesterol in laying hens. Br. Poult. Sci. 51, 791-796.

Shapira, N., 2010. Every egg may have a targeted purpose: toward a differential approach to egg according to composition and functional effect. Wrld Poult. Sci. J. 66, 271-284.

Simcic, M., Stibilj, V. \& Holcman, A., 2009. The cholesterol content of eggs produced by the Slovenian autochthonous Styrian hen. Food Chem. 114, 1-4.

Sparks, N.H.C., 2006. The hen's egg - is its role in human nutrition changing? Wrld Poult. Sci. J. 62, 308-315. 
Tercic, D., Levart, A. \& Holcman, A., 2010. Cholesterol content in eggs produced by hens divergently selected for body weight. Arch. Tierz.-Arch. Anim. Breed. 53, 701-707.

Usturoi, M. \& Radu-Rusu, R.M., 2006. Alternative solutions to be used in laying hens' husbandry, Bullet. Cluj-Napoca Univ. Agric. Sci. Vet. Med. 62, 32-36.

Wang, X.L., Zheng, J.X., Ning, Z.H., Qu, L.J., Xu, G.Y. \& Yang, N., 2009. Laying performance and egg quality of blue-shelled layers as affected by different housing systems. Poult. Sci. 88, 1485-1492.

Zemkova, L., Simeonovova, J., Lichovnikova, M. \& Somerlikova, K., 2007. The erects of housing systems and age of hens on the weight and cholesterol concentration of the egg. Czech J. Anim. Sci. 52, 110-115. 